Relations industrielles

Industrial Relations

\title{
The Conciliation of Labour Disputes
}

\section{II - Conciliation from the Inside Viewpoint}

\section{Léopold Jasmin}

Volume 6, numéro 3, juin 1951

URI : https://id.erudit.org/iderudit/1023223ar

DOI : https://doi.org/10.7202/1023223ar

Aller au sommaire du numéro

Éditeur(s)

Département des relations industrielles de l’Université Laval

ISSN

0034-379X (imprimé)

1703-8138 (numérique)

Découvrir la revue

Citer cet article

Jasmin, L. (1951). The Conciliation of Labour Disputes: II — Conciliation from the Inside Viewpoint. Relations industrielles / Industrial Relations, 6(3), 81-83. https://doi.org/10.7202/1023223ar

Tous droits réservés @ C Département des relations industrielles de l’Université Laval, 1951
Ce document est protégé par la loi sur le droit d'auteur. L’utilisation des services d’Érudit (y compris la reproduction) est assujettie à sa politique d'utilisation que vous pouvez consulter en ligne.

https://apropos.erudit.org/fr/usagers/politique-dutilisation/ 
union justify its demands. The conciliator does not have any less work when the parties are before him because they have exhausted up to this point a lot of arguments supporting their respective positions. It is then necessary to find new arguments to get one or the other to accept a viewpoint different from his own.

As conclusion to these few remarks on some of the problems that a conciliator meets, one can only invite the parties to co-operate. This attitude will have for result more friend- ly employer-employee relationships in our Province. At the present time, one out of three cases goes to arbitration and this percentage can be improved by a greater mutual understanding.

It can be taken for granted that in all circumstances, the conciliator will do his utmost to help the parties come to an agreement. Conciliation, in fact, has not as its aims to delay arbitration procedures, but to attempt to reach a solution of the problems.

\title{
II - CONCILIATION FROM THE INSIDE VIEWPOINT
}

\author{
by LÉOPOLD JASMIN
}

This brief article does not pretend to define conciliation, nor to explain its techniques. At the most it attempts to underline certain aspects of a useful and interesting work which is in the centre of what sociologists group under the general heading of "human relations".

In an employer-employee dispute, we mention only two parties as being involved. It is taken for granted that there is identical interests on the part of capital and management on the employer side and equally identical interests on the part of the workers and the union leaders. In reality, the situation is sometimes more complex. Management may attach more importance to some of its prerogatives than to wage rates, whereas the holders of capital see in any increase in salaries a measure by which their profits may be reduced. On the other hand, the employees are especially interested in the salary, whereas their union leaders may add to this objective the preoccupation of union organization or expansion. This lack of unity on behalf of one or the other party to a dispute may result in added difficulty or, on the other hand, may help bring a final settlement. Salary, for example, may be exchanged against union security or management prerogatives against salary.

A case where there is necessarily subdivision of the parties, is one in which the dispute concerns a decree under the Collective Agreement Act. The employer group includes many employers of which the problems, the mentality and the enterprises are different. This results in re-groupings by region, size of enterprise, etc., with repercussions on the workers' side. There again, this complex situation may render the work of the conciliator easier or more difficult as the case may be. In the end, it is usually a question of competition which it is necessary to balance.

The worst thing that the parties can do for themselves or for the conciliator is to form a negotiating committee with too many members. If each one has his say, the discussion drags out indefinitely. On the contrary, those who do not get everything said that they want to say during the meetings, make up for it between meetings by adopting a negative attitude on the compromises which might be submitted to them. Too numerous a group seldom 
reaches unanimity and the old Latin proverb "tot sensus quot capita" is always true. On the other hand, it would not be desirable to have each party represented by only one person because it is always possible to find face to face with each other two persons of which the character or the ideas render them hostile to one another. I believe that in general, a group of two to five negotiators for each party is what is best, provided that these representatives be sufficiently authorized to make decisions.

Whatever be the number or representation of the parties, if a conciliator is added, it results in a meeting which groups just about all the human passions, without forgetting the seven capital sins.

The majority of the disputes which go to conciliation have the principal characteristic of being sharpened because they have not been settled during the stage of private negotiations. One of my friends divides them in "important matters" and "unimportant matters" in basing himself on the number of employees involved or the size of the enterprise to evaluate the difficulty of the case. The reality is not quite so simple.

The small marginal enterprises, that a difference in cost price or selling price may throw into bankruptcy, negotiate bitterly. They fight for their very existence againts the workers' claims which are even more insistent as these enterprises usually have working conditions below the average. They are often directed by an employer who has been a worker, who is proud of his success, of his value, of the sacrifices he has made to raise himself to the rank of employer. He would like to put all his personnel through the same trials, without taking into account the individual differences, nor the changes that have taken place since the time he was himself an employee. This employer has not always an agreeable personality. He is often crafty: many French-Canadians have Norman ancestors. The conciliator must use patience, persuade him to negotiate in good faith, overcome his reluctance to come to terms with a labour organization. Especially to resist the temptation to send him up before an arbitration board, leaving his employees the task of finishing to convince him by the strike argument, which would perhaps only make him hold on more stubbornly to his prejudices.

In large-scale industry, negotiating with a union is not questioned. Negotiations are carried on with improved technique. As the enterprise is more prosperous, it can act more generously towards its employees. A higher degree of mechanization, markets more stable and often monopolistic or partly-monopolistic in character, make it easier to better working conditions of the employees. On the other hand, these enterprises may make a stubborn resistance to the union's demands that they consider, rightly or not, as exaggerated.

We usually divide labour disputes in conflicts of interest and conflicts of right. Disputes arising during the negotiation of agreements are conflics of interest with implications of an economic and social nature. Grievances regarding the interpretation or carrying out of clauses of an agreement in force are conflicts of right because they concern the reciprocal rights of the parties as set down by the agreement. But as these latter conflicts frequently carry implications of a social or economic nature, they can often be reduced to conflits of interest. It must not be forgotten that the disputes dealt with by conciliation are of a nature demanding action and that they require first of all a practical solution. This is important for the conciliator, because he may be obliged, occasionally, if he wants to settle the dispute and not to make it worse, to put 
aside the solution that is most correct theoretically, to adopt one that is in practice more acceptable to the parties involved. If space permitted, it would be interesting to point out cases where a conflict of rights has ended in a practical settlement which was suitable to both parties, whereas the interpretation or the complete application of the agreement would have meant a deadlock. It is not unusual that an employer or a workers' association prefers to have peace rather than be right.

As regards the comparable difficulty of the two kinds of conflicts, I believe that an agreement represents a series of exchanges between employers and employees. There are many different combinations possible. It is necessary to help the parties find the one which is suitable for them. A grievance does not leave much place for mutual concessions and often brings up problems which would be more within the jurisdiction of a court of justice than that of a conciliator.

During the last war, certain employers amusingly described the conciliator as "the Government official who comes in after the union has taken all that it could, that helps it to take away still more of what we were refusing and then often sends us before the Arbitrators to bring about final complete surrender." Many union leaders would endorse this de- finition reversed in favour of the employers. Unless this one is preferred "the Government employee who comes to see which is the weaker of the two parties and then knocks it down until it gives in."

In fact, the conciliation officer, is a government official, an employee of the State, whose function consists of trying to bring to an agreement the parties in an employer-employee dispute. $\mathrm{He}$ is not a police official, as some employers with a fearful conscience seem to think. $\mathrm{He}$ is not a Don Quixote, to right wrongs. Nor is he a propagandist entrusted to aid the triumph of union claims or to maintain management prerogatives. He may have his own ideas on social questions and use his contacts to expound them, but he must not forget that it is not his place to make principles obtain a victory or propagate ideas, his place is to cooperate towards the maintenance of industrial peace in which the State and all the community are interested.

A knowledge of law, economics, accounting, statistics, psychology etc. may help the conciliator in his work. But as many problems that he touches involve several of the above at once, and, moreover, he has but little time or methods of study at his disposition, he must try to be a man of Wisdom, leaving to the Arbitrators the science and the bitter fruits of the conciliations in which he has not succeeded.

The problem of the age is how to reestablish the dignity and authority of the great truths without which history is nonsense:...the essential freedom of man, the power of his reason, the fact that he cannot really live without God, his absolute thirst after truth, the proper place he occupies in the universe, and how he may enter into the full life of community with his fellow men. Any understanding that does not have regard to these truths is a snare and a illusion. . The future belongs to the country and people... firmly grounded in these matters.

Charles Malik 